\title{
PRINTING MOLDS OF PAPER MONEY OF THE KHOREZM PEOPLE'S SOVIET REPUBLIC
}

\author{
Mohamed, $\mathrm{H}$. \\ Islamic archaeology dept. Faculty of Archeology, Cairo Univ., Giza, Egypt \\ E-mail: hadhood_hs85@yahoo.com
}

\begin{abstract}
By the end of the $13^{\text {th }} A H / 19^{\text {th }} A D$ century and the beginning of the $14^{\text {th }} A H / 20^{\text {th }} A D$ century, Khorezm witnessed an important phase of its history, which ended in the Russian occupation, the abolition of the Khiva Khan ateregime and the proclamation of the People's Republic of Khorezm in $1339 A H / 1920$ AD. During that period, the monetary system underwent major changes as the silk and paper currencies began to emerge and the local currency was converted from the tenga, tilla and felus into the Russian ruble. This study aims to deal with a set of metal molds used to print the banknotes of the People's Republic of Khorezm during the period of 19221923 by means of a set of bronze molds preserved in the Museum of Ichan Qala in Khiva, where this period witnessed the spread of paper money. The study tackles these molds through the identification of raw materials, methods of industry, techniques and stages of printing, in addition to the inscriptions printed on them and other decorations, emblems and symbols, with the analysis of their contents, along with a comparison of these templates with models of the remaining paper money, which represent the categories of these molds.
\end{abstract}

Keywords: Khorezm, Paper Money, Printing Molds, Seals, Tenga, Tilla, Felus

\section{Introduction}

Khorezm $^{(a)}[1]$ was famous for the manufacture of gold, silver, and copper seals and molds. Such seals were rings that bore the names of their owners, whether they were khans, princes, senior state officials, employees, or merchants. These seals were used to sign decrees, documents, agreements, treaties, commercial contracts and arguments. The museums of Uzbekistan retain many of these types, as well as seals used in minting coins and printing paper and silk money. It is worth mentioning that in the closet of Muhammad Rahim Khan (1281- 1328 AH/1864-1910 AD) there were twenty golden and five silver seals belonging to the Khan, and about two hundred dies for striking money [2]. It is, also, noteworthy that in $1290 \mathrm{AH} /$ 1873 AD, the Russian traveler and civil servant Kun, acting upon the orders of the governor-general of West Turkistan, to transferred four Poods (Russian weight 1pood $=16 \mathrm{~kg}$ ) of seals to St. Petersburg, which are now preserved in the Hermitage Museum [3]. The manufacture of seals and molds has been an important branch of the metal industry in Khorezm towards the end of the $13^{\text {th }} \mathrm{AH} / 19^{\text {th }} \mathrm{AD}$ century and the beginning of the $14^{\text {th }} \mathrm{AH} /$ $20^{\text {th }} \mathrm{AD}$ century, where it had special workshops and craftsmen specialized in manufacturing them. One of the most famous groups of metal industry in Khiva 
during that period was the family of Machanov, whose members were famous for the manufacture and engraving of metal seals [4]. The collection of metal molds under study consists of six bronze molds preserved in the warehouse of the Museum of Ichan Qala in Khiva dated 1340-1341 AH/1922-1923 AD, a period that witnessed the spread of paper money in Khorezm. These molds represent different monetary denominations and designs of a variety of Khorezm banknotes struck during that period. The importance of these seals lies in the fact that they give us a view of the techniques of industry and decoration of a major branch of the metal industry in Khorezm during the first quarter of the $14^{\text {th }} \mathrm{AH} / 20^{\text {th }} \mathrm{AD}$ century, as well as in that it helps us identify the forms of

\section{Khorezm and the Monetary System}

During the second half of the $12^{\text {th }}$ $\mathrm{AH} / 18^{\text {th }} \mathrm{AD}$ century, the internal conflict for power continued in Khiva and the clan of Qunqrat gained sovereignty over the rule of the khanate (chief of the tribe) in the name of the Khan [5]; the earliest of these Inaqs mentioned by Muraviv was Ishmed bi. He was succeeded by his son, Muhammad Amin, who became Inaq in $1169 \mathrm{AH} / 1755 \mathrm{AD}$, and during that period there were no coins for khanate. The coins of Bukhara and money used for trade in Khorezm during that period, and the impact of the political conditions on printing paper money. By the end of the $13^{\text {th }} \mathrm{AH} / 19^{\text {th }} \mathrm{AD}$ century and the beginning of the $14^{\text {th }} \mathrm{AH} / 20^{\text {th }}$ AD century, Khorezm was familiarized with a new type of money, made of silk, in addition to the coins that were previously circulated. Such silk banknotes are extremely scarce and we have not obtained samples of the seals and molds used in the printing process. Moreover, paper money was used in Khorezm during that period when such molds were being used in printing, and models of such paper money are already available. In fact, the examination of these molds has always been part and parcel of the printed banknotes.

Iran were used [2]. Then, during the reign of Inaq Eltuzar Khan (1219-1221 AH/1804-1806 AD), who became the first Shah of the Qunqrat in $1219 \mathrm{AH} /$ $1804 \mathrm{AD}$, the khanate achieved its greatest regional expansion [6], in which both gold and silver coins were struck. In this regard, Abdu al-Karim al Bukhary states that Eltuzar khan struck coins under his name, but he was short in time to issue them, and they bore the following inscription:

$$
\text { "بفضل من الله ختم إلتوزار وريث ملوك خو ارزم اسمه على الذهب و الفضة"[7] }
$$

During the reign of Muhammad Rahim Khan (1221-1241 AH/1806-1825 $\mathrm{AD})$, the khanate collapsed economically. Consequently, Muhammad Rahim Khan established a higher council of senior officials and representatives of the Uzbek tribe to handle the major affairs of the state. He also reformed the tax system and introduced tariffs on the markets. In turn, with the steady growth of Khorezm foreign trade, striking gold and silver coins started [8]. According to Muraviv, Muhammad Rahim Khan issued a series of arbitrary taxes and established a tax collection house and another to strike gold and silver coins [2]. The money traded in the khanate consisted of gold tilla $^{(b)}$ [9], silver tenga ${ }^{(c)}[10]$, and copper felus $^{(\mathrm{d})}$, in addition to Bukhara and Persian metal coins and even German coins [2]. Moreover, important information on monetary circulation in Khiva is also reported in the records of Nikolai Muraviv who visited it in 1235- $1236 \mathrm{AH} / 1819-1820$ AD. According to him, there were gold coins of tilla, silver tenga and copper "Qarapul" in circulation, in which one tilla was equal to 4 Russian silver rubles, 
and the tenga was the same size as the Russian grivennik (a piece of 10 kopek) made of high quality silver and was valued at 15 Russian silver kopek [3]. During his son's era, Allah Quli Khan (1241 - 1258 AH/1825 - 1842 AD), the boundaries of khanate extended [8] and many of the coins were struck under the name of Allah Quli Khan Bahadir Khan, and it is peculiar to find the revival of khanate's old name "Khorezm" on the coins upon which the mint has been mentioned [2]. Then, during the reign of Sayyid Muhammad Khan bin Muhammad Rahim Khan (1273-1281 AH/ 1856-1864 AD), Tuhlewein states that there were two types of gold coins: "Tillas" issued in the khanante, one was worth 12 shillings and the other about 6 shillings, while the silver coin "Tenga" was worth around seven pence and "Shahi" with around three pence; 48 copper felus or "Qarapuls" coins comprised a tenga [2]. During this period, Russia was determined to occupy Khiva, against which successive Russian campaigns were launched, until the campaign led by General Kaufman took over Khiva on May 29, 1873 AD (1290 AH), which ended with the extradition of the Russians. Muhammad Rahim Khan II (1281-1328 AH/ 1864-1910 AH) signed an agreement with Kaufman that stipulates the Khan's protection of Russian merchants, exempting them of all taxes, and to cover the costs of the military campaign of 2.200.000 rubles to be paid by Khanate in several installments, for which payment is made in Russian or Khiva currency only [11]. The close economic relations of Bukhara and Khiva with Russia towards the end of $1298 \mathrm{AH} / 1880 \mathrm{AD}$ necessitated a stable relationship between the Russian currency and those of the allies. However, by the beginning of the mid-nineties of the nineteenth century there was a sharp decline in the universal price of silver, which weakened such a relationship. Usually, the mints in both Bukhara and Khiva struck the tengas, in which each Bukharian tenga contained 8.22 grams of silver with a value of 20 Russian kopeks in $1298 \mathrm{AH} / 1880 \mathrm{AD}$ and then it decreased to the value of 10 kopek only in 1312 $\mathrm{AH} / 1894 \mathrm{AD}$ as a result of the decline of silver prices, at the time when the exchange rate on Bukharian tenga was about 20 kopek. At the beginning of the 1990s, brokers bought a silver ingot in Russia to be used in striking the tenga in Bukhara that was exchanged in Russia for rubles, making huge profits in the process. This led to a decline in the exchange rate of the tenga down to 18 kopeks in $1312 \mathrm{AH} / 1894 \mathrm{AD}$, but the difference between the value of the exchange and the value of silver encouraged profit and dealings. The same thing happened with the Khivan tenga but on a smaller scale [12]. In February and March 1894 AD (1312 AH), a delegation was established within the Ministry of Finance under the leadership of T. F. Kubiko to study the problems of Russian trade with Bukhara and Khiva, recommending the unification of the monetary system of areas under Russian protection with Russia [12]. In $1322 \mathrm{AH} / 1904 \mathrm{AD}$ and in $1326 \mathrm{AH} / 1908$ AD K. K. Pahlen, member of the Senate, conducted a thorough investigation into the general affairs of Turkestan. In 1326 $\mathrm{AH} / 1908 \mathrm{AD}$, he recommended to accept the Khivan tenga in the Petro-Alexandrovysk treasury for the value of 20 kopeks with the gradual and comprehensive withdrawal of the currency from circulation, replacing it with the Russian currency. Under pressure from Petro-Alexandrovysk, $\mathrm{Mu}-$ hammad Rahim issued a decree for the free circulation of Russian paper money [12]. In 1328 AH/1910 AD, the Prime Minister of Russia held a meeting and decided to integrate Khiva with Russia and enforced the use of the Russian currency instead of the currency of Khiva, but prevented the implementation of the war resolution between the Uzbeks and yomut Turkumans $^{(\mathrm{e})}$ [13] since (1313-1355 AH/ 1912-1916 AD) [14]. After the revolution of February 1336 AH/1917 AD in Russia, which ended the Czarist rule that lasted under of the Romanovs, Junaid Qorban Muhammad Ali took over 
Khiva in 1335 AH/1916 AD and declared himself in charge of the affaires of the Khan. Then in 1337 AH/1918 AD, Isfandiar Khan was killed but he was unable to declare himself the Khan of Khiva, handing the throne over to Abdullah Khan, Isfandiar's brother, and Junaid Khan became the actual ruler of Khiva Khanate [14]. During the reign of Badishah Sayyid Abdullah (1337-1399 AH/1918-1920), khanate's economy was in a crisis. His government represented in the military council under the presidency of Junaid was engaged in a monetary reform, as the state did not have sufficient paper suitable for the purpose. The Khorezm mint was established in the first quarter of the $13^{\text {th }} \mathrm{AH} / 19^{\text {th }} \mathrm{AD}$ century in Kunya Ark and the large registered denomination of banknotes were issued on locally produced silk fabrics. The first edition of silk coins in khanate of Khiva dates back to $1337 \mathrm{AH} / 1919 \mathrm{AD}$, with five denominations of 200, 250, 500,1000 , and 2500 tengas, and during that time five tengas of Khiva khanate were worth one Russian ruble. Then, in $1338 \mathrm{AH} / 1920 \mathrm{AD}$, the second edition of silk money was minted. Five denominations of 200, 250, 500, 1000 and 2500 were converted to the Russian monetary system. Finally, the third edition of silk money of Khiva khanate (the so-called 'vertical') (1338 AH/1920 AD) was of two denominations only, namely 100 , 250 rubles [15]. According to the sources, during the reign of Sayyid Abdullah Khan (1337-1399/1918-1920) he issued three million rubles of banknotes, whether silk or paper [15]. The Soviet army was able to take over Khiva and the Khan was forced to abdicate in $1339 \mathrm{AH} /$ February 1920, Khiva khanate's regime was abolished, and the Khorezm People's Republic was declared. And, in the principal law of Khorezm People's Republic, the name khanate of Khiva was replaced by the old name Khorezm [14]. On April 11, 1921 (1340 AH) the Soviet Republic of Turkestan was formed, and Russia seized control of foreign affairs, foreign trade and military affairs. On the $29^{\text {th }}$ of July 1922, a new economic agreement was signed with Khorezm, and according to this agreement all customs barriers and border guards on the border of Turkmenistan-Khorezm were abolished [16]. Besides, the silk money of Khiva was replaced by paper money at the Economic Reform Conference held in Tashkent in March 1923A.D [15]. During the period from September 1924 to May 1925, the map of Turkestan changed completely, and the Republics of Turkestan, Khorezm and Bukhara ceased to exist and together came to be known as the Soviet Socialist Republic of Uzbekistan. It includes the northwest, central and eastern Bukhara, south of Khiva, Ferghana and Samarkand, the southern part of the Syr Darya region and Pamir [16]. Despite of the continuation of minting coins in Khorezm until 1338 AH/1919 AD based on a coin issued during the reign of Junaid Khan, silk and paper money in khanate of Khiva started to appear after that, and continued to be issued even after the announcement of the Khorezm People's Republic. The first issue since the declaration of the Republic was in $1339 \mathrm{AH} / 1920 \mathrm{AD}$, depending on the presence of several bronze molds dated $1338 \mathrm{AH} / 1920 \mathrm{AD}$ for the denominations of 750 and 1000 rubles kept in the Museum of Ichan Qala, while the last version was issued in $1341 \mathrm{AH} / 1923$ $\mathrm{AD}$, considering the available banknotes and printing molds. Then the local currencies, namely the gold tilla, silver tenga and copper felus, were converted to the Russian ruble. According to the remaining banknotes so far, the issuance of paper money in $1340 \mathrm{AH} / 1921 \mathrm{AD}$, included only the denominations of 5.000, 10.000 (which was distinguished by two different designs), and the 25.000 rubles. In the year 1341AH/1922 AD, banknotes with variant categories were issued, starting from the lowest denominations as follows $(1,3,5,10,25,100,5,000,10.000,25.000$ rubles). The collection under study includes one mold for the denomination of 10.000 manats/rubles used to issue the banknotes of the same category during that year. 
2.1. Mold number (1), fig. (1)

Bronze mold "obverse", denomination 10.000 manats/rubles, dated 1340 AH/1922 AD, size: $12 \times 17 \mathrm{~cm}$, Inv. КП 881/8-4, preserved at Ichan Qala Museum in Khiva. A rectangular mold divided into two parts: the upper left one is occupied by a rectangular frame, bearing an inscription in Uzbek:

$$
\text { "خوارزم شور الار جمهوريتى نينگ كاغد تنحه سى" }
$$

Which means: The paper money of the Khorezm Soviet Republic ${ }^{(*)}$.Below it to the right is a diamond shape with the word "Khorezm" inside it, executed in the mirror script, and under it, the

$$
\text { "أوشبو كاغد تتحه نينح ساخته قليخان كيشى نى انقلاب اجر محكمة صى غه تإيشيريلور " }
$$

Which means: "That who counterfeits the currency will be punished by the revolutionary court". The right part

has a circular medallion with an inscription in Uzbek in four lines:

$$
\begin{aligned}
& \text { أوشبو كاغد تتخه } \\
& \text { حكومت نبنك بونون } \\
& \text { ملكى ابلان تامين } \\
& \text { إيتولكُاندور تامين }
\end{aligned}
$$

Which translates as: "The government guarantees this paper currency with all its material assets". It is surrounded by floral motifs of carnation and plant leaves, under it there is a text in Uzbek: "اون مينك منات", which means 10,000 rubles. Below this part, there is a half circular medallion with the date " 1340 ", and in the corners of this part there is an inscription " 10.000 ". In the beginning, I thought that the history recorded on this template dates back to $1345 \mathrm{AH} / 1926$ $\mathrm{AD}$, after the abolition of the Khorezm People's Republic, but after matching this date with a paper money dated 1340
AH/1922 AD, it can be concluded that it is registered in the same shape on the mold, and also by matching the number of the denomination 10.000 engraved on the sides of the mold it becomes clear that zeros are implemented in the same way as the form of number five but in a smaller size. Concerning the paper money of Khorezm issued in $1341 \mathrm{AH} /$ 1923 AD the year Khorezm elimina-ted the silk money and replaced it with paper money, it can be studied through the examination of the similarly-dated metal molds used in printing. The denominations of these molds are as follows:

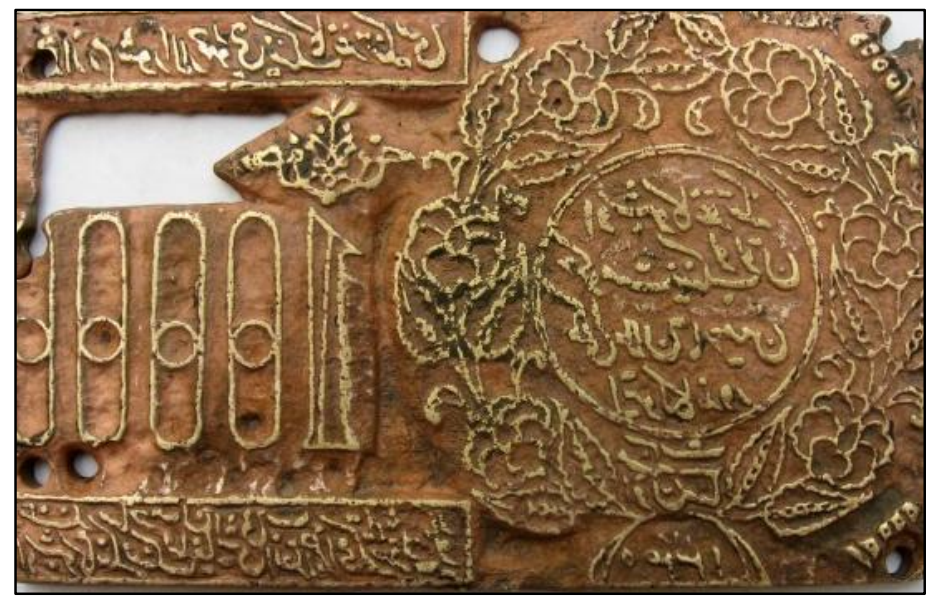

Figure (1) Shows bronze mold "obverse", denomination 10000 manat / rubles, dated 1340 AH / 1922 $\mathrm{AD}$, preserved at Ichan Qala Museum in Khiva. 


\subsection{Mold number (2), fig. (2)}

Bronze mold "reverse", denomination 25 manat/rubles, dated $1341 \mathrm{AH} /$ 1923 AD, size $8 \times 10 \mathrm{~cm}$, Inv. КП 892, preserved at Ichan Qala Museum in Khiva. A rectangular bronze mold with a

$$
\text { " خوارزم خلق شور الار جمهورينى كاغد آقجه سى" }
$$

This means: "The paper money of the Khorezm People's Soviet Republic", below which there is a rectangular shape. Then there are two inscriptional bands: in the right one a text is written in

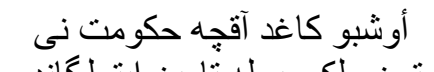

$$
\begin{aligned}
& \text { بوتون ملكى برله تامين ايتولكاندور }
\end{aligned}
$$

Which means: "the government guarantees this paper currency with all its material assets", and in the middle a semi circular arch with the date 1341. Although there is no banknote available for this denomination, it is noted that there are several deep areas in the mold that may have been dedicated to a special type of seals used with this mold, as well as an area free of inscriptions at the bottom of the mold.

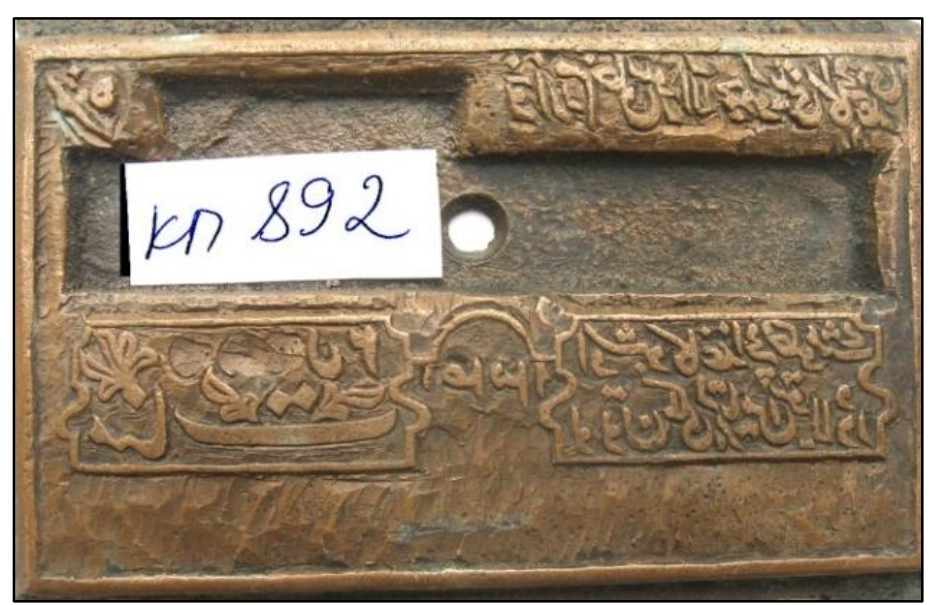

Figure (2) Shows Bronze mold "reverse", denomination: 25manat/rubles dated 1341 AH/1923 AD, preserved at Ichan Qala Museum in Khiva.

\subsection{Mold number (3), fig. (3-a)}

Bronze mold "obverse", denomination 50 rubles, $8 \times 14 \mathrm{~cm}$, dated 1341/ 1923, Inv. КП 891, preserved at Ichan Qala Museum in Khiva. A rectangular bronze shape with a shape of a hollow oval in the middle, with four round medallions in the four corners, the right and left carved in Russian "50 РУБЛИИ", which means 50 rubles. While the upper medallion has the date 1923, and the lower one 1321, and to confirm the denomination; the craftsman carved the word "РУБЛЕИ" in Russian on the edges of the medallion which means rubles. The frame is an oval double one, with a round medallion in between, inside which a repeated inscription in Uzbek " المنگ سى", while in the four corners of the mold there is a triangle framed by twisted forms known as "chashmi bulbul" which means the eye of a nightingale, with a floral design of a rose of four petals and leaves in the middle. It is noted that this mold has both the Hijri and the Gregorian dates, besides the name of the currency which is inscribed 
six times in Russian with the denomination written twice, while it is not engraved in Uzbek nor it shows the usual Russian slogans. Comparing this mold to a currency of the same denomination, it is clear that this mold was to print the reverse of the paper and not the obverse. In the middle of the oval shape, there is a deep area in the mold that may have been dedicated to another seal with geometrical designs and an inscription in Uzbek in two lines as follows:

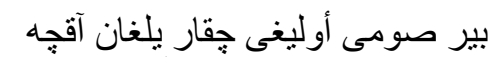

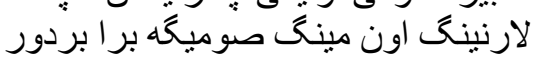

This means "one sum is equivalent to 10.000 sums of the old currency,"

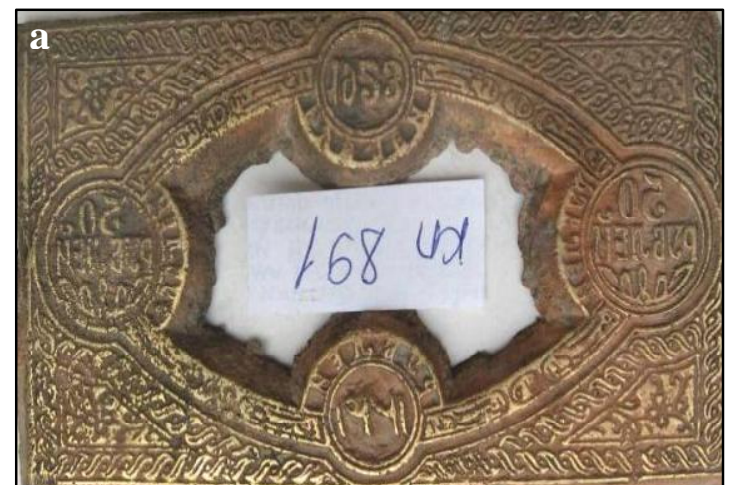

and it is noted that the color used in printing is black and red, fig. (3-b).

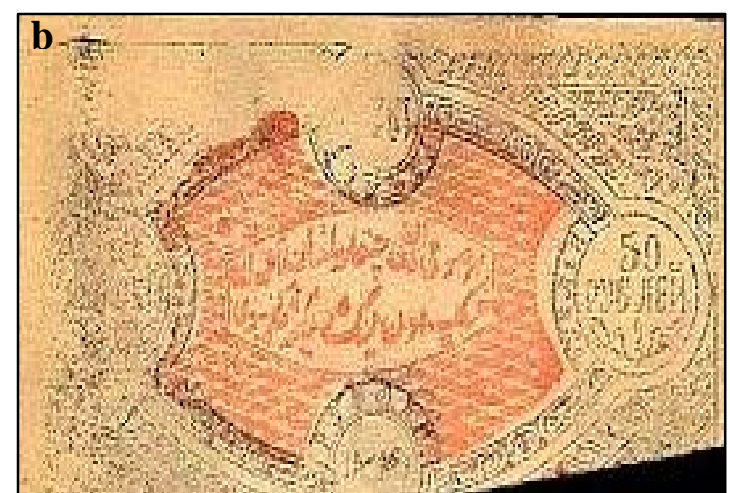

Figure (3) Shows a. Bronze mold "obverse", denomination 50 rubles, dated 1341/1923, Inv. КП 891, preserved at Ichan Qala Museum in Khiva, $\underline{\mathbf{b}}$. paper money, denomination 50 rubles, 1341/1923, www.numismondo.net

\subsection{Mold number (4), fig. (4-a)}

Bronze mold" obverse", denomination 100 rubles/manat, dated 13401341 AH/1922-1923 AD, preserved at Ichan Qala Museum in Khiva. A bronze rectangular mold concaved in the bottom. It is shaped with two oval medallions; each is decorated with the word "يوز منات" 100-rubles inscription in Uzbek, and in Russian "100 РУБЛЕИ"to the upper part, with the word "khorezm" between floral designs underneath, and a rectangular frame below surrounding an inscription in Uzbek in two lines:

$$
\text { شور الارحكومنى نى آقجه سى }
$$

This means: "The paper currency of the Soviet government". The edge of the mold is surrounded by a prominent frame of only three sides: the right and

$$
\text { "بير صومى اوليغى جقار يلغان آقهـ لارنينگ صوميخه برا بردور" }
$$

Which means: one sum equals 10.000 sums of the old currency, with floral designs to the right and the left. This mold combines the nominal value of the denomination and the name of the currency in Russian and Uzbek languages, as well as the implementation of the word "khorezm" separately between the inscriptions, which was lack of the word" Republic", that used to appear on the molds of the Republic of Khorezm. Comparing this mold with a currency from the same denomination, it is obvious that this mold was intended for printing the obverse and not the reverse, with three rectangular seals printed in the lower part of the printed currency with a negative mold; which 
means that the craftsman left a part of it cut or without relief. This procedure was the main reason for the unity of the denomination, yet there is a difference between the seals that hold different names which can be used according to the current circumstances, and that's why the seals were separated from the molds to allow them to be changed easily. Besides, this was a precautionary procedure on the part of the mint against falsifycation by keeping these seals and those responsible for printing them themselves. Usually the three seals represent the seal of the Minister of Finance, the
Chairman of the Council of People's, Treasurer [15].These seals were usually used to print the reverse and not the obverse, fig. (4-b). Although there is no date on this mold, by reference to the remaining securities and printed currency of this mold, it is determined that banknotes in this category (100 rubles) were issued in the same format in two consecutive years (1922 and 1923, namely) and therefore the obverse is fixed and the reverse changed according to the year of issue, whether its 1922 or 1923 , fig. (4-c).
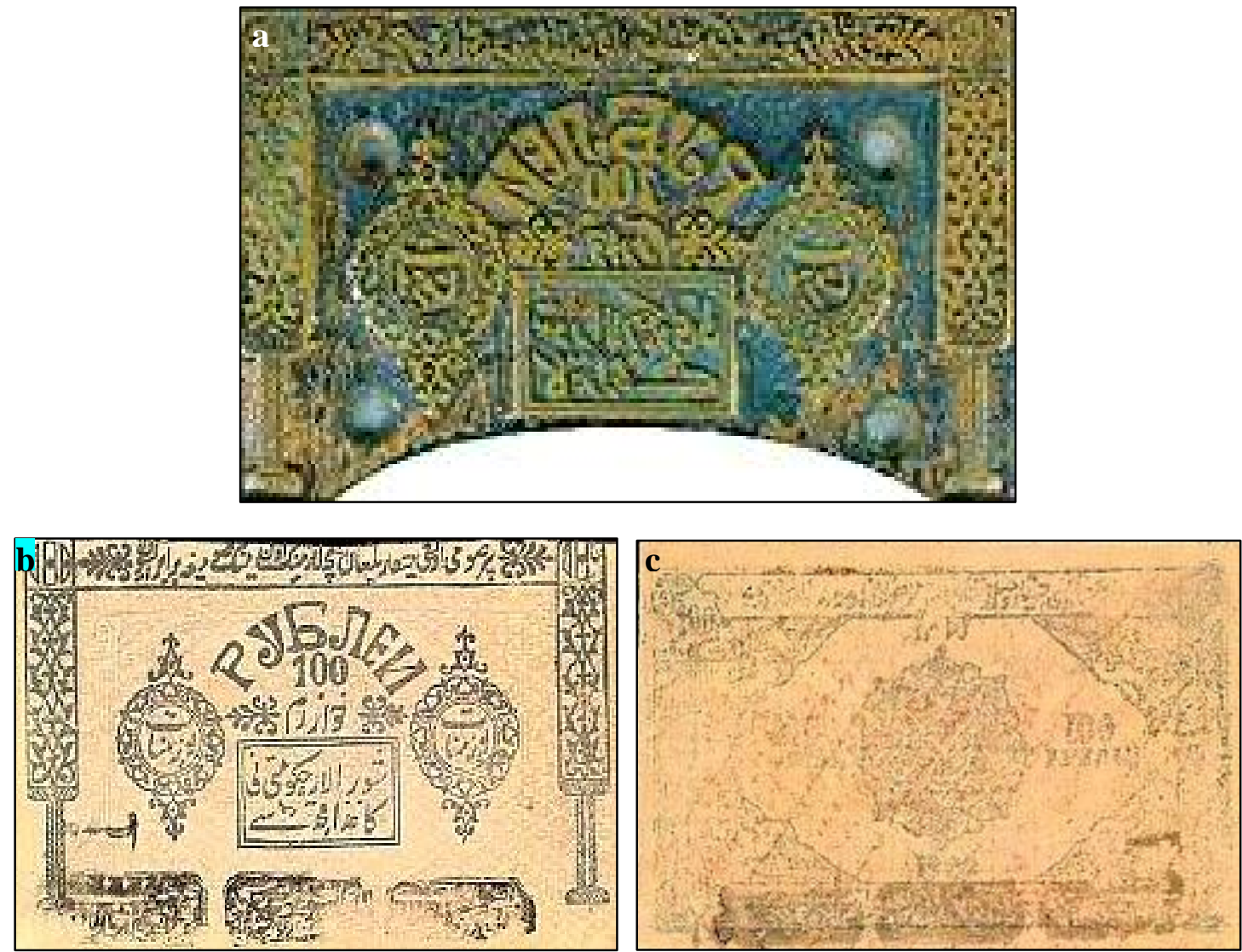

Figure (4) Shows a. bronze mold "obverse", denomination 100 rubles / manat, dated 1340-1341AH / 1922-1923AD, preserved at Ichan Qala Museum in Khiva, $\underline{\mathbf{b}}$. paper money, denomination 100 rubles, www.numismondo.net, $\underline{\mathbf{c}}$. paper money, denomination 100 rubles, $1341 \mathrm{AH} /$ 1922AD, www.numismondo.net.

\subsection{Mold number (5), fig. (5-a)}

Bronze mold (reverse), denomination 500 rubles, dated 1341AH/1923AD, $7 \times 11 \mathrm{~cm}$, Inv. КП 896, preserved at Ichan Qala Museum in Khiva. A rectangular bronze mold, with an inscription in Uzbek in Arabic letters on the top of the left side: خوارزم جمهورينى كاغد آقجه سى meaning "the paper money of the Khorezm Republic", and on the right there is another obliterated inscription. In the middle of the mold, there is a medallion with floral designs with 
another round medallion with a drawing of crescent, star and a sickle. There are two cross wands, with two branches representing the wheat spines surrounded by a frame with an inscription in Russian "РУБЛИИ" for rubles, and to the four sides of the medallion there are four small circles with the denomination "500", with the dates 1341 and 1923 to the right and the left sides. In the middle to the bottom of the mold a phrase in Uzbek reads:

$$
\text { "اوشبو كاغد آقجه جمهوريت نى بونون ملكى بيلان تامين ايتولحاندور" }
$$

Meaning: the Republic guarantees this currency with all its financial assets. This mold is distinguished by having both the Hijri and the Gregorian date without the denomination in Uzbek. Comparing this mold with a cash sheet of the same denomination, it is clear that this mold is intended to print the
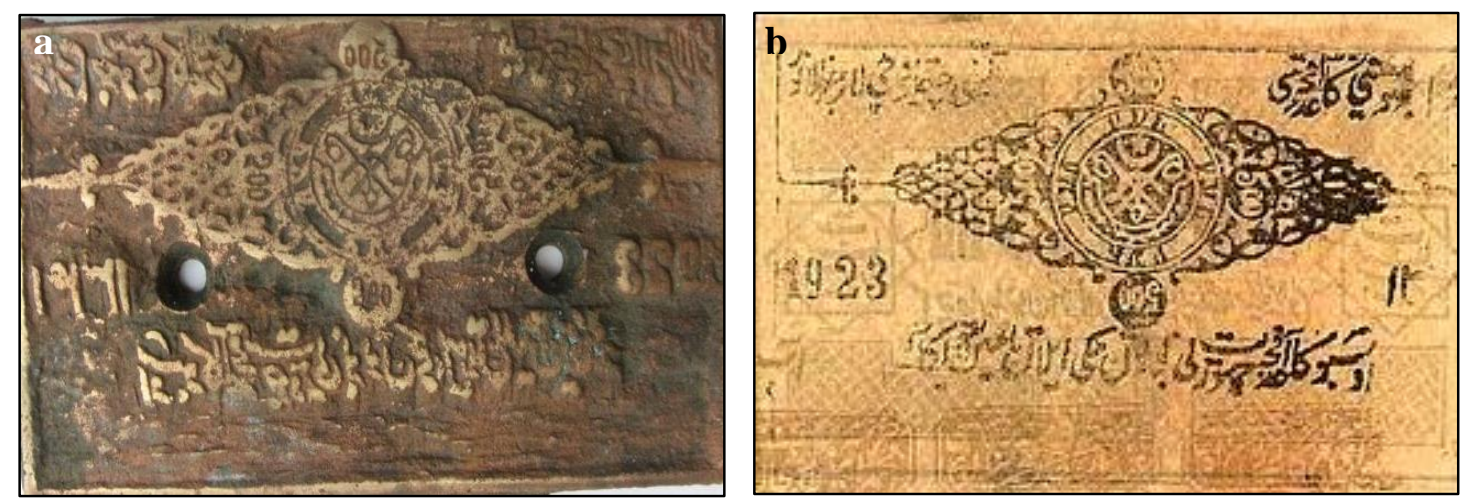

Figure (5) Shows a. . Bronze mold (reverse) denomination 500 rubles, dated 1341AH /1923AD, preserved at Ichan Qala Museum in Khiva, $\underline{\mathbf{b}}$. paper money, denomination 500 rubles, dated 1341 AH / 1923AD, www.numismondo.net.

\subsection{Mold number (6), fig. (6-a)}

Bronze mold "reverse", denomination 1000 rubles, dated $1341 \mathrm{AH} / 1923 \mathrm{AD}$, size $12 \times 17 \mathrm{~cm}$, Inv. 903/30-2 KП, preserved at Ichan Qala Museum in Khiva. A rectangular bronze mold, with a concave central part with an oval medallion decorated with a crescent, a hexagonal star, a sickle, and two cross wands, with two

$$
\text { "بيرصومى اوليغى جقار يلغان آقجه لارنينگ اون مينگ صوميحه برا بردور" }
$$

Meaning: one sum equals 10000 sums of the old currency. This part is surrounded by two frames that occupy the inner frame of three ornamental corners,

$$
\text { "خوارزم جمهوريتى كاغد آقجه سى " }
$$

Meaning "the paper money of the Khorezm Republic", while the outer border is made up of straight lines. Comparing this which are made up of four-petalled foliage. The upper part of this frame has another rectangular frame that is wider and filled with an inscription:

mold with a cash sheet of the same denomination, it becomes obvious that this mold is intended for printing the 
reverse of the paper, not the obverse. Also, three rectangular seals at the bottom printed in a negative mold, are identified. Therefore, the craftsman left this part in the mold without engraving. It is noted

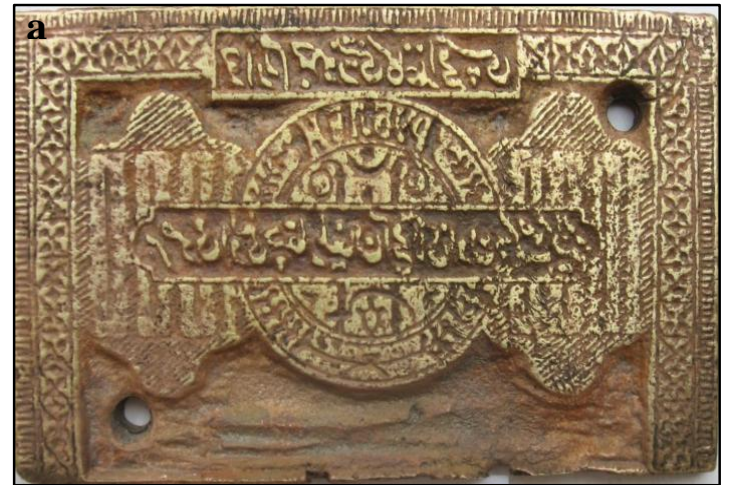

that the color used in printing is black and brown. It is, also, obvious that the print was produced using the mold first, then the three seals, fig. (6-b).

Figure (6) Shows ‥ bronze mold "reverse", denomination 1000 rubles, dated 1341AH / 1923AD, preserved at Ichan Qala Museum in Khiva, $\underline{\mathbf{b}}$. paper money, denomination 1000 rubles, www.numismondo.net.

\section{Analytical Study}

The main objective of the analytical study of metal molds is to investigate the shapes and sizes of these molds, the raw material used in their manufacture, the

\subsection{Shape and size}

The majority of the molds are of rectangular shapes and vary in size according to the required cash category, of which some mold types are considered for this study such as: $8 \times 10 \mathrm{~cm}$ for 25 manat / rubles, $7 \times 11 \mathrm{~cm}$ for 500 rubles, $8 \times 14 \mathrm{~cm}$ for 50 rubles, $12 \times 17 \mathrm{~cm}$ for both the1000 and 10,000 rubles molds. The size of a mold correlates with the value and class of the intended banknote. So, larger templates were used to produce

\subsection{Raw material}

M. S. Kozhukhin believes that the silk printing molds in Khiva were made of elm timber because of the use of wooden molds in textile printing. However, we have no access to samples of such molds.

\subsection{Method of manufacturing and decoration}

These molds were made by means of casting, which is proved by the different blank spaces in the bronze mold. After designing the appropriate design for the monetary category to be printed, the process of engraving on the mold begins.

methods and techniques of their manufacture, the involved techniques of printing securities, the inscriptions registered on them, and their decorations, as follows:

higher-value banknotes on larger papers. While, it is not confirmed that the majority of the molds were rectangular based upon initial observation, as some of the molds date back to $1338 \mathrm{AH} / 1920 \mathrm{AD}$ (preserved in Ichan Qala museum), it is noticed that they take many different shapes, and not all even, as the molds were made separately then used in printing the banknotes, which however come in even shapes.

Besides, there were separate units for each color, and the printing process was isolated [15], while the bronze molds were used in printing the banknotes of the Republic of Khorezm.

The engraver used the deep prominent engraving "Kandakori" and the concave one for inscriptions and decorative elements executed on the surface of the mold by engraving pens and the hammers. These inscriptions were also executed in reverse, 
in order to show the printed patterns in color on the surface of the paper money in a modified or corrected manner. Thus,

\subsection{Techniques of printing money}

After preparing the paper for the printing process, the manufacturer dipped the mold in the color to be used on the surface of the paper, and the colors used to print paper money according to the remaining models are black, red and blue. These colors were locally made from traditional local oak dyes on pistachio leaves, dried flowers, cochineal of Indian origin, and madder. The dyes were based on apricot glue [15]. The printing process is carried out by pressing the paper with the template in several stages, like the silky Khorezm currency, and printing the molds in more than one stage. This is illustrated by the remaining banknotes compared to the molds under study like the mold of the 50 rubles, which was embossed in two stages: the first is represented by the main mold under study, while the other was carried out using an- the molds under study represent the positive and negative molds, simultaneously.

other mold and a different color. At other times, the printing is completed in three stages. This process can be recognized in a currency dated $1338 \mathrm{AH} / 1920$ $\mathrm{AD}$, with the denomination 750 rubles, which is distinguished by three different colors, for the frame, the inscriptions, and the design on one side of the banknote. The Ichan Qala museum preserves three templates that were used to print such banknotes. This museum also keeps the remains of a large sheet of with imprints of a 500 rubles mold dated $1341 \mathrm{AH} /$ 1923 AD, which indicates that the template was applied more than once on a large sheet of paper, then the procedure of cutting starts later, fig. (7). It is observed that the molds under study are more orderly and systematic than the seals and molds used in printing silk currencies.

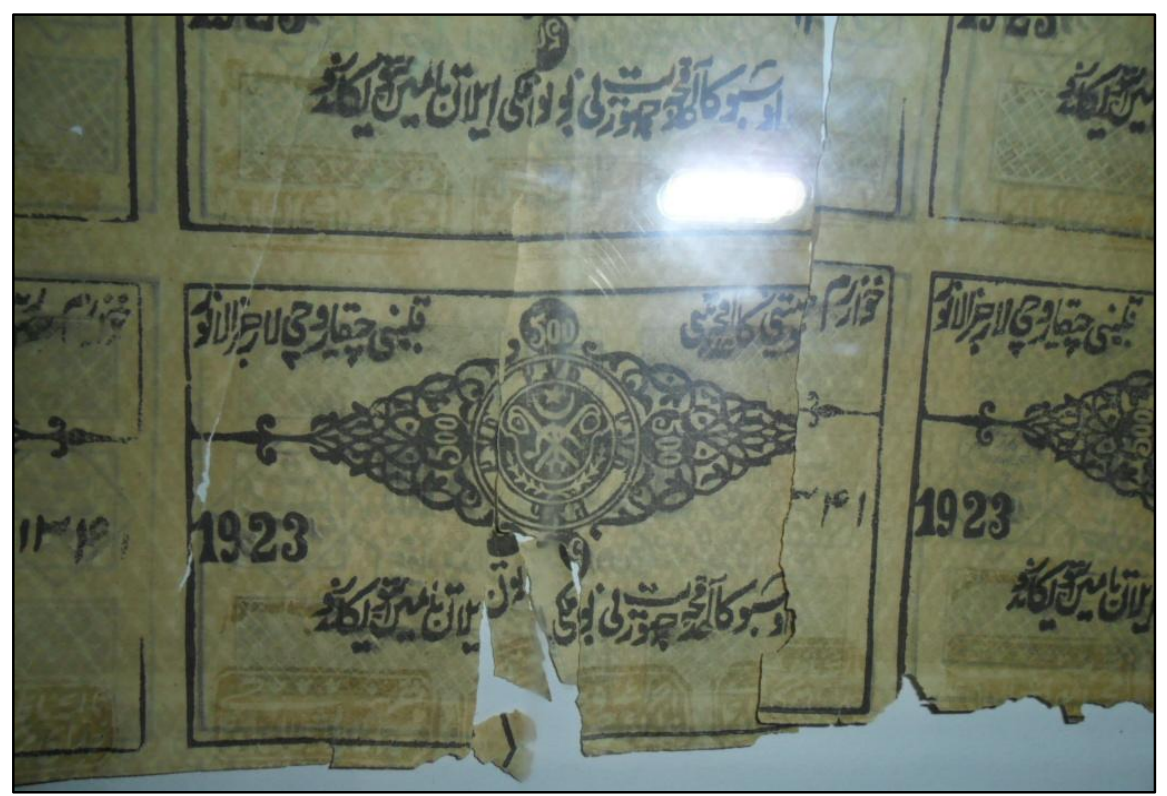

Figure (7) Shows large sheet of paper money, denomination 500 rubles, dated 1341AH / 1923AD, preserved at Ichan Qala Museum in Khiva

\subsection{Inscriptions}

Most inscriptions on the templates are written inscriptions that provide the dates, the name of the currency, the nominal values of the denominations, the numbers, the mint, in addition to some special-content phrases. The Persian and Uzbek languages were engraved in Arabic letters unlike the modern Uzbek written in Russian letters. 


\subsubsection{Dates}

The engraver was keen to record the date of issue by writing the Hijri date in Persian language, as well as the

\subsubsection{The name of the currency, and its denomination}

The currency on the molds is the ruble and was recorded in Russian "РУБЛИИ", along with the correspondding name of the currency in Uzbek under the name manat [15]. The use of the Russian currency, language and culture was due to the influence of the Russian expeditions since the middle of $13^{\text {th }} \mathrm{AH} / 19^{\text {th }} \mathrm{AD}$ century in Central Asia [2]. This period was characterized by Russian pressures on Khorezm and an

Gregorian date in Latin on the same template.

increasing Russian influence. The Russians even attempted to replace the Arabic alphabet in the Uzbek scripts with the Russian alphabet. Additionally, the government was keen to confirm the value of the currency and its worth of ten thousand times more than the old currency, as well as the word "sum", which is the name of the currency now used in the Republic of Uzbekistan in the form:

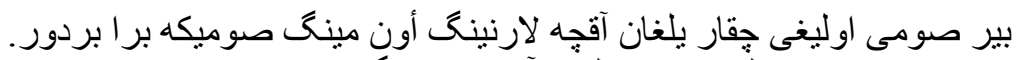

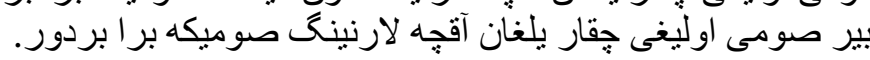

Most of the molds under study were issued in 1341 AH/1923 AD, and represent different categories of 25, 50, 100, 500, and 1000 rubles. The denominations of the ruble were issued by the Republics of Khorezm and Bukhara-which were under Russian protection-differ from the denominations issued in Russia itself which were known as Soviet rubles. The different categories of the ruble continued to be issued until the elimination of the Republic of Khorezm. The inscriptions 3.5.3. Phrases of special content

On the templates, there are expressions indicating the government's keenness to warn citizens against falsifying money

on the molds include dates and numbers written in Latin which represent the nominal value of the issued category, as the engraver who represents the mint was keen to record it more than once, in more than one position on the same template, both in Russian and Uzbek languages, as well as in letters and numbers. This was a continuation of the same tradition of writing the name of the category that appeared on paper currencies and molds in 1339 AH/1920 AD.

of any form, with promises of punishment. For example:

$$
\text { أوشبو كاغد تنحه نينى ساخته قليغان كيشى نى انقلاب اجر محكمة صى غه تإيشيريلور. }
$$

These terms were recorded on the silk currency before, as noted by the government and the Republic to ensure these

paper currencies in more than one formula such as:

$$
\begin{aligned}
& \text { أوشبو كاغد آقهه حكومت نى بوتون ملكى بر له تامين ايتولكاندور. }
\end{aligned}
$$

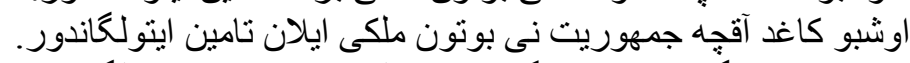

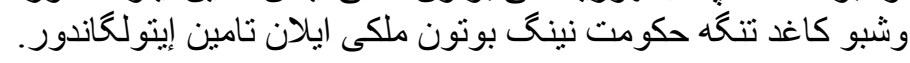

Moreover, it is noted that the mint was keen to make it clear that this currency

belongs to the new Republic declared after the termination of the khanate:

$$
\begin{aligned}
& \text { خوارزم خلق شور الار جمهوريتى كاغد آقهِه سى خو ارزم جمهوريتى كاغد آقجه سى - خوارزم شور الار }
\end{aligned}
$$

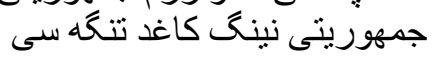

Which means "the paper money of the People's Republic of Khorezm" which was the new name acclaimed by the new Republic, instead of the previous Khiva 
khanate as it was engraved on coins along with the name Dar Al-Islam Khorezm or Dar Al-Saltanah Khorezm. While on the 100 rubles mold the phrase reads: شور الار حكومنى بى كـاغد آقجه سى waphich translates as "the People's Government", 3.5.4. Script's type and shape

The script used in the Uzbek inscriptions on the molds was the nasta'liqscript, which was popular in the Central Asian until the end of the $13^{\text {th }} \mathrm{AH} / 19^{\text {th }} \mathrm{AD}$

\subsection{Floral and geometrical designs}

The floral elements and geometrical forms executed on the molds are the same as the technical traditions followed in the decoration of Khorezm applied arts, especially ceramic tiles and metal works. One of them was the unnatural floral element with its various designs of roses, flowers, vases, plant leaves, half palmette leaves, as well as real motifs such as the carnation تشينى كل. The geometric shapes are represented in the form of square,

\subsection{Emblems and symbols}

The most important emblems that appeared on the molds and therefore printed on paper money are: Crescent "Oybola" the sun and the crescent are of the elements that appeared on the Khorezm coins the pentagram "Yelduz" [17], sickle, wheat spikes and mace stick, which are presented in two ways, one vertical and the other horizontal. The star symbolizes the ruling Communist Party, while the sickle, also associated with the hammer, symbolizes workers and peasants who are

\section{Results and Discussion}

Therefore, through the pervious study of these metal molds, many important results can be concluded, as follows: 1) Most of the molds under study are issued in $1341 \mathrm{AH} / 1923 \mathrm{AD}$, represent different categories of 25, 50, 100, 500, and 1000 rubles. The denominations of the ruble issued by the Republic of Khorezm and Bukhara, which were regions under the Russian protection at the time, differ of the denominations issued in Russia itself which were known as the Soviet rubles. so the word "Republic" was not mentioned on this template, while the name of the mint was mentioned on some of the separate molds from the Republic in the form of "Khorezm" only.

century and the beginning of the $14^{\text {th }} \mathrm{AH} / 20^{\text {th }} \mathrm{AD}$ century, both in architecture and applied arts.

rectangular and oval frames, as well as the geometric tress shapes of chashmibulbul تشانشمى بلبل, the upright forms, the shapes of medallions, arches, and inscriptional bands. In some cases, floral or geometric motifs were engraved on a separate mold apart from the basic mold of inscriptions and other seals. The Ichan Qala Museum in Khiva retains a bronze mold of this type.

the foundation of the communist society. These symbols are copied from the design of both the flag and emblem of the Soviet Union, which were adopted in 1341 AH/1923 AD. In fact, these new Soviet decorative elements, such as the pentagram, hammer, sickle, etc. were used by the engravers after the revolution of $1336 \mathrm{AH} / 1917 \mathrm{AD}$ and illustrate the various types of applied arts produced by the Uzbeks in 1339-1359AH/19201940AD [18].

The different categories of the ruble continued to be issued until the elimination of the Republic of Khorezm. 2) Most of the molds are rectangular and vary in size according to the required cash category, and are slightly smaller than the size of the printed banknotes. So, the more value the money category held, the larger the size of the template and the paper were. 3) Bronze was the main raw material utilized to manufacture the banknote molds of the Republic of Khorezm. They were 
made via means of casting. While the deep prominent engraving was the most prominent decorative feature in the work, while inscription and decorative elements were executed on the templates. 4) The printing process is carried out by means of pressing the paper with the template in successive stages, such as the silky Khorezm currency, and printing the molds in more than one stage. This is illustrated by the remaining banknotes compared with the molds under study, like the 50 rubles mold, which was embossed in two stages: the first is represented by the main mold under study, while the other was done by another mold in another color. At other times, the printing is completed through three stages, which is illustrated by a currency dated 1338 AH/1920 AD, with the denomination of 750 rubles distinguished by three different colors, for the frame, the inscriptions, and the design on one side of the banknote. 5) Most of the inscriptions on the templates are written inscriptions illustrating the dates, the name of the currency, the nominal values of the denominations, the numbers, the mint, in addition to some phrases that have special contents.
6) The script used in the Uzbek inscriptions on the molds was the nasta'liq-script, while the Persian, Uzbek and Russian languages were used in the inscriptions. 7) The engraver was keen to record the date of issue by writing the Hijri date in Persian language, as well as the Gregorian date in Latin on the same template, in numbers and not in letters, as the engraver who represents the mint was keen to record it more than once, in more than one position on the same template, in Russian and Uzbek languages, both in letters and numbers. This was a continuation of the same tradition used in the registration of the name of the category that appeared on paper currencies and molds in 1339 AH/ 1920 AD. 8) The currency on the molds was the ruble and was recorded in Russian "РУБЛИИ", along with the corresponding name of the currency in Uzbek under the name "manat". 9) On the templates, there were expressions indicating the government's keenness to warn citizens against falsifying the money in any form, promising punishments for falsifiers. Moreover, it is noted that the mint was keen to record that this currency was for the new Republic, which appeared after the termination of the khanate through this phrase:

$$
\begin{aligned}
& \text { خوارزم خلق شور الار جمهورينى كاغد آقُه سى - خو ارزم جمهورينى كاغد آقجه سى - خو ارزم شور الار } \\
& \text { جمهوريتى نينح كاغد تنحكه سى }
\end{aligned}
$$

Which means the paper money of the Khorezm People's Republic was the name assured by the new Republic, instead of the name of Khiva khanate.

10) The floral elements and geometrical forms executed on the molds are the same as the technical traditions follo- wed in the decoration of applied art of Khorezm. On the molds there are some Soviet emblems and symbols taken from the design of both the flag and emblem of the Soviet Union, which were adopted in $1341 \mathrm{AH} /$ 1923 AD.

\section{Conclusion}

After the declaration of the People's Republic of Khorezm in 1339 H./1920 A.D., the monetary system changed drastically: silk and paper money appeared, and the local currency was replaced by the Russian Ruble. This study aims at investigating a collection of metal molds that were being used to print paper money between 1922 and 1923 A.D. Such molds are particularly significant as they reflect the techniques of manufacture and inscription in that sector of the metal industry of Khorezm, during that period of time. They also reveal to us the shapes and forms of the currencies circulated in Khorezm, as well as the inscriptions and writings they bore, reflecting the political atmosphere of that era. By studying and comparing 
the remaining banknotes of different monetary values, several significant conclusions are made that reveal more about the history and culture of the region and inform researchers of Central Asia in general, and Khorezm in particular.

\section{Acknowledgements}

The author is indebted to Mr. Kamlgan Rahimof, head of researchers in Al-Bayrouny Institute for Eastern Scripts in Tashkent in Uzbakistan for translating the text from Uzbek into Arabic

\section{Endnotes}

(a) Geographically, the oasis of Khorezm lies to the east and south of the Aral Sea, on both sides of the lower reaches of the Oxus (Amu Darya), and around its delta estuary. It also comprises the formerly inhabited areas between the Amu and the Syr Darya as well as the southern part of the arid plateau Ust-Urt, south-west of the Aral Sea [1].

(b) It is a gold coin, smaller and much thinner, called the tilla, the value of which varies according to the rate of exchange, and probably with the amount of precious metal of the coin. The Khokandian tilla is valued at nineteen tengas, and the Bukharan tilla at from twenty-four to twenty-eight tengas. In Khiva, there were two types of tillas, the large which equals eighteen tengas, and the small which equals [9].

(c)Tenga is a silver coin, with a weight heavier than the dirham ranges between 4-5.5 grams. It was circula-

\section{References}

[1] Knobloch, E., (1972). Beyond the ous, archaeology, art and architecture of Soviet central Asia, $1^{\text {st }}$ ed., Ernest Benn Ltd, London.

[2] Howorth, H., (1880) History of the Mongols from the $9^{\text {th }}$ to the $19^{\text {th }}$ century, Part II, Longmans, Green \& Co. London.

[3] Rtveladze, E., (2003). Eastern and northern central Asia (1750 to 1850), in: Adel, C. \& Habib, I., (eds.) History of Civilizations of Central Asia, Vol. V, UNESCO, pp: 448-454

[4] Abdullayev T., Fakhretdinova, D. \& Khakimov, A., (1986). A song in metal:

ted in the Mongol and Turk countries, and from there it spread to Iran and India. During the Timurid era, it bore the Islamic testimonies of faith "Shahadah", with the names of the Rashidun Caliphs (Rightly Guided Caliphs) around it on the obverse, while on the reverse it bore the Timurid ruler's name with his titles, also the mint and date of strike [10].

(d) The qarapul was minted from copper. The minting was very poor. Fourty qarapuls were the equivalent of 1 tenga, and 1 qarapul was the equivalent of 1.5 Russian copper kopeks. It was the same size as the Russian polushka (quarter-kopek piece), but two or four times thicker [3].

(e) Yomut is one of the six Turkuman tribes living in Khiva. The town of Yomut was about 20 miles northwest to Khiva [13].

Folk art of Uzbekistan, Gafur Gulyam Art and Literature Pulishers, Tashkent.

[5] Annanepesov, M., (1996). The khanate of Khiva (Khwarazm), in: Adel, C. \& Habib, I., (eds.) History of Civilizations of Central Asia, Vol. V, UNESCO, pp: 65-73

[6] Barthold, W. \& Bril M., Khiwa, (1986). The Encyclopedia of Islam, Vol. V, in: Bosworth, C., Van Donzel, E., Lewis, B. \& Pellat, Ch. (eds.), BRILL. E.J., Leiden.

[7] Boukhary A., (1876), Hisoire De L' Asie centrale Afghanistan, Boukhara, Kiva, Khoqand, Hachette Groupe Livre, Paris 
[8] Matyakub, M., Masharipov, B. \& Abdrasulov, A. (2001). Khiva, guide book, RUZ Co Pub., Moscow.

[9] Schuyler. E., (1877), Turkistan, Notes of a journey in Russian Turkistan, khokand, Bukhara and kuldja, $\mathrm{Vol}_{\mathrm{s}}$ .1.2, Scribner, Armstrong \& Co, NY.

[10] Ramadan, A., (2011). Al-Nkoud alIslamiya wa ahmyatha fe derast altarikh wal-hadara wal-athar alislamiya (The significance of islamic currencies for the study of islamic history, monuments and civilization), $2^{\text {ed }}$., Zahraa El-Sharq, Cairo.

[11] Pierce R., (1960). Russian central Asia 1867-1917, a study in colonial rule, Univ. of California press, USA.

[12] Seymour, B., (1969), Russia's protectorates in Central Asia; Bukhara and Khiva, 1865-1924, Russian Research Center Studies, No. 54, Cambridge, Mass.: Harvard Univ. Press, London

[13] MacGahan, J., (1847), Oasis of Khiva, $J$. of the American geographical society of New York, Vol. 6, pp. 116-137
[14] Al-Terazy, N., (2010), Turkistan, madyha wa haderha (Turkistan: the past and the present), $1^{\text {st }}$ ed., Maktabit Al-Adab, Cairo.

[15] Богословская, И. \& Голендер, Б., (2009). Хоразмнингшойи пуллари (Silk money from Khorezm), Sau'am: J. of the Academy of Arts of Uzbekistan, Vol. 4, pp: 1-6

[16] Lobanoff, R., (1928), The Soviet Muslim republics in central Asia, $J$. of the royal institute of international affairs, Vol.7 (4), pp: 241-255

[17] Пугаченкова Г. \& Ремпель, Л., (1960). Художественный металл, выдающися памяаники изобразительного искусства Узбекистана, (Metal art, outstanding, monuments of fine art of Uzbekistan), State Literature Publishing House of Uzbekistan, Ташкент.

[18] Сергеев, Б., (1960), Чеканка по меди, государственный музей ис-кусств Узбекистана (Copper embo-ssing: state art museum of Uzbekistan), Publishing House of Literature RSSZU, Ташкент. 